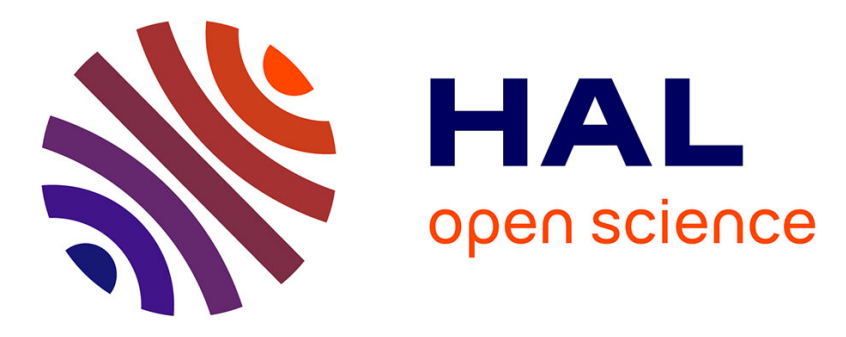

\title{
Hydrogen sorption properties of the nanocomposites Mg-Mg2Ni1-xFex
}

\author{
Jean-Louis Bobet, Elie Grigorova, Maria Khrussanova, Mitko Khristov, \\ Dimitar Radev, Pavel Peshev
}

\section{- To cite this version:}

Jean-Louis Bobet, Elie Grigorova, Maria Khrussanova, Mitko Khristov, Dimitar Radev, et al.. Hydrogen sorption properties of the nanocomposites Mg-Mg2Ni1-xFex. Journal of Alloys and Compounds, 2002, 345 (1-2), pp.280-285. 10.1016/S0925-8388(02)00435-8 . hal-00738242

\section{HAL Id: hal-00738242 \\ https://hal.science/hal-00738242}

Submitted on 11 Jan 2021

HAL is a multi-disciplinary open access archive for the deposit and dissemination of scientific research documents, whether they are published or not. The documents may come from teaching and research institutions in France or abroad, or from public or private research centers.
L'archive ouverte pluridisciplinaire HAL, est destinée au dépôt et à la diffusion de documents scientifiques de niveau recherche, publiés ou non, émanant des établissements d'enseignement et de recherche français ou étrangers, des laboratoires publics ou privés. 


\title{
Hydrogen sorption properties of the nanocomposites $\mathrm{Mg}-\mathrm{Mg}_{2} \mathrm{Ni}_{1-x} \mathrm{Fe}_{x}$
}

\author{
J.-L. Bobet ${ }^{\mathrm{a}, *}$, E. Grigorova ${ }^{\mathrm{b}}$, M. Khrussanova ${ }^{\mathrm{b}}$, M. Khristov ${ }^{\mathrm{b}}$, D. Radev ${ }^{\mathrm{b}}$, P. Peshev ${ }^{\mathrm{b}}$ \\ ${ }^{\mathrm{a}}$ Institut de Chimie de la Matière Condensee de Bordeaux (ICMCB), CNRS [UPR 9048], Universite Bordeaux 1, \\ 87 Avenue du Docteur A. Schweitzer, 33608 Pessac Cedex, France \\ ${ }^{\mathrm{b}}$ Institute of General and Inorganic Chemistry, Bulgarian Academy of Sciences, Acad. G. Bonchev Str., Building 11, 1113 Sofia, Bulgaria
}

\begin{abstract}
The hydrogen sorption properties of the composites 85 wt. $\% \mathrm{Mg}-15$ wt. $\% \mathrm{Mg}_{2} \mathrm{Ni}_{1-x} \mathrm{Fe}_{x}(x=0,0.1$ and 0.3$)$ prepared by high-energy ball milling were studied. It was shown that the presence of a $\mathrm{Mg}_{2} \mathrm{Ni}_{1-x} \mathrm{Fe}_{x}$ additive significantly improved the kinetics of hydrogen absorption and desorption of magnesium, the absorption capacity remaining sufficiently high even at temperatures between 423 and 573 $\mathrm{K}$. The catalytic effect of the $\mathrm{Mg}_{2} \mathrm{Ni}_{1-x} \mathrm{Fe}_{x}$ intermetallics was explained as due to the formation of a second hydride, $\mathrm{Mg}_{2} \mathrm{NiH}_{4}$, to the appearance during the mechanical alloying of defects facilitating the formation of hydride nuclei and to the presence of $\mathrm{Ni}$ and $\mathrm{Fe}$ clusters on the surface of nanocomposite particles.
\end{abstract}

Keywords: Hydrogen absorbing materials; Nanostructures; Mechanical alloying; Gas-solid reactions; X-ray diffraction

\section{Introduction}

One of the promising properties of magnesium and its alloys is the possibility of reversible formation of hydrides. Unfortunately, the high absorption capacity of magnesium (7.6 wt. $\% \mathrm{H}_{2}$ ) is attained after preliminary activation at high temperature and pressure. Its hydriding kinetics are poor below $600 \mathrm{~K}$, which is also the minimum temperature needed for the dehydriding reaction. For that reason, a large number of investigations have been aimed at improving the hydriding-dehydriding kinetics of magnesium by preparing composites on its basis with an absorption capacity close to that of pure magnesium.

During the past years, high-energy ball milling has proved to be a suitable method for the preparation of such composites with improved hydrogen sorption properties. Ball-milling results in formation of a pure and reactive surface with dislocations and other defects [1-3]. The additives present in the composites along with magnesium very often play the role of catalysts in the hydriding and dehydriding processes. Thus, mechanical alloying is a simple way of introducing a catalyst into the reaction system $[4,5]$.

\footnotetext{
*Corresponding author. Tel.: +33-5-5684-2653; fax: +33-5-56842480.

E-mail address: bobet@icmcb.u-bordeaux.fr (J.-L. Bobet).
}

Various substances have been used as additives to the magnesium nanocomposites obtained by ball milling. In a series of papers $\mathrm{Mg}$ is mechanically alloyed with some transition metals $(\mathrm{Ce}, \mathrm{Ti}, \mathrm{Nb}, \mathrm{Fe}, \mathrm{Co}, \mathrm{Ni})$ [6-10] or an intermetallic additive like $\mathrm{MNi}_{5}$ (pure or partially substituted $\mathrm{LaNi}_{5}, \mathrm{MmNi}_{5}$ or $\mathrm{YNi}_{5}$ [11-18]), $\mathrm{FeTi}_{12}$ [19], $\mathrm{ZrNiCr}$ [20], $\mathrm{ZrNi}_{16} \mathrm{Cr}_{04}$ [20] and $\mathrm{ZrFe}_{14} \mathrm{Cr}_{06}$ [21,22]. Nickel belongs to a special category as it forms with magnesium the intermetallic compound $\mathrm{Mg}_{2} \mathrm{Ni}$ able to absorb hydrogen reversibly as a ternary hydride, $\mathrm{Mg}_{2} \mathrm{NiH}_{4}$. The possible important applications of hydrogen storage materials of the $\mathrm{Mg}-\mathrm{Ni}$ system are the reason for a large number of papers dealing with them, the most important results having been summarized recently in a review of Orimo and Fujii [23].

Depending on the nature and quantity of the additive, its catalytic effect on hydriding and dehydriding of magnesium may be due to the appearance of: (i) new intermetallic phases; (ii) binary metal hydrides with a varying stoichiometry which may 'pump' hydrogen to the magnesium surface; and (iii) clusters of transition metals on the surface of $\mathrm{Mg}$ particles playing the role of active sites for dissociative chemisorption of hydrogen.

The present paper represents a continuation of the authors' work on the hydrogen storage characteristics of magnesium mechanically alloyed with various additives $[11,15,18,24]$. As was pointed out above, $\mathrm{Mg}_{2} \mathrm{Ni}$ absorbs 
hydrogen with formation of the ternary hydride $\mathrm{Mg}_{2} \mathrm{NiH}_{4}$, which is accompanied by an increase in the volume. In the literature there is also information on the catalytic effect of iron clusters when they are present on the surface of the magnesium particles. In view of this it is of interest to establish how a magnesium composite containing $\mathrm{Mg}_{2} \mathrm{Ni}$ or $\mathrm{Mg}_{2} \mathrm{Ni}_{1-x} \mathrm{Fe}_{x}$ would behave during hydriding-dehydriding. A composite of that kind could combine the high hydrogen absorption capacity of magnesium with the lower dehydriding temperature of $\mathrm{Mg}_{2} \mathrm{Ni}$. On the other hand, the presence of iron in the composite should also have a favourable effect on the hydriding kinetics.

\section{Experimental}

Powdery magnesium, nickel and iron of $99.9 \%$ purity were used for the preparation of $\mathrm{Mg}_{2} \mathrm{Ni}$ and $\mathrm{Mg}_{2} \mathrm{Ni}_{1-x} \mathrm{Fe}_{x}$ $(x=0.1$ and 0.3$)$. Mixtures having the corresponding composition were pelleted and heated under argon at 823 $\mathrm{K}$ for $120 \mathrm{~h}$. The samples obtained were mechanically, ground with magnesium (85 wt.\% $\mathrm{Mg}+15$ wt.\% $\mathrm{Mg}_{2} \mathrm{Ni}_{1-x} \mathrm{Fe}_{x}$ ) in a Fritsch Pulverisette 5 planetary ball mill to obtain mechanically alloyed composites. The grinding proceeded under argon using stainless steel balls (diameter $=10 \mathrm{~mm}$ ) and container (volume $\approx 75 \mathrm{~cm}^{3}$ ), the balls to sample weight ratio being 10:1. The rotation speed of the mill was $200 \mathrm{rpm}$ and the milling time, $30 \mathrm{~min}$.

The hydrogen absorption-desorption characteristics of the mechanically alloyed samples thus obtained were determined by the volumetric method described in Ref. [25]. The hydriding reaction proceeded at $T=373,423$,
473 and $573 \mathrm{~K}$ and a pressure of $1 \mathrm{MPa}$. Hydrogen desorption was measured at $T=573 \mathrm{~K}$ and $P=0.15 \mathrm{MPa}$.

The phase composition of the initial intermetallics and the hydrided and dehydrided mechanically alloyed samples was controlled by X-ray phase analysis using $\mathrm{Cu} \mathrm{K} \alpha$ radiation.

With a view to checking the composition and homogeneity of $\mathrm{Mg}_{2} \mathrm{Ni}_{0}{ }_{9} \mathrm{Fe}_{01}$ and $\mathrm{Mg}_{2} \mathrm{Ni}_{0}{ }_{7} \mathrm{Fe}_{03}$ alloys, electron microprobe analyses were performed using a CAMECA SX-100 instrument.

\section{Results and discussion}

The X-ray phase analysis data of the obtained initial intermetallic phases show that the $\mathrm{Mg}_{2} \mathrm{Ni}$ sample is almost single-phase. According to the results reported in [26], $\mathrm{Mg}_{2} \mathrm{Ni}_{1-x} \mathrm{Fe}_{x}$ alloys having a $\mathrm{Mg}_{2} \mathrm{Ni}$-type structure with hexagonal symmetry exist at least up to $x=0.25$ if prepared by melting of the elements at $1173 \mathrm{~K}$. In the present study preparation has occurred at $823 \mathrm{~K}$ and the X-ray patterns indicate a free iron content not only in the sample with nominal composition $\mathrm{Mg}_{2} \mathrm{Ni}_{0_{7}} \mathrm{Fe}_{0_{3}}$, but also in $\mathrm{Mg}_{2} \mathrm{Ni}_{09} \mathrm{Fe}_{01}$. The calculated values of the cell parameters $(a=5.20-5.21 \AA ; c=13.22-13.24 \AA)$ are close to those of pure $\mathrm{Mg}_{2} \mathrm{Ni}$.

Microprobe analysis of the $\mathrm{Mg}_{2} \mathrm{Ni}_{0}{ }_{9} \mathrm{Fe}_{0}$ sample reveals the presence of nickel and iron clusters. As can be seen in the backscattering electron microphotograph in Fig. 1 , each cluster is surrounded by a ring containing $\mathrm{Mg}$ and $\mathrm{Ni}$ with a prevailing $\mathrm{Ni}$-content and both the cluster and the ring are immersed in the matrix of a $\mathrm{Mg}_{2} \mathrm{Ni}$-type phase containing traces of Fe. The presence of nickel agglomer-

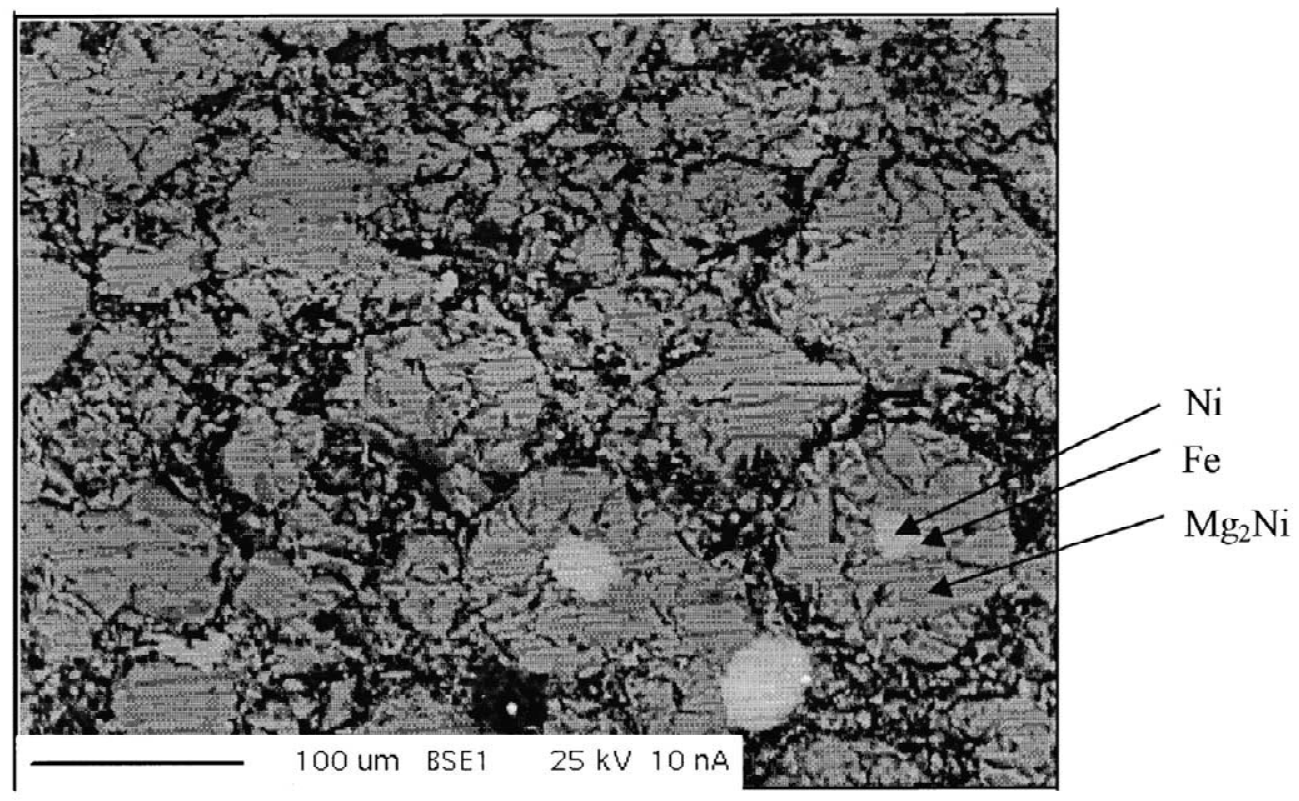

Fig. 1. Backscattering electron microphotograph of the $\mathrm{Mg}_{2} \mathrm{Ni}_{0.9} \mathrm{Fe}_{0, .1}$ sample showing the presence of: (i) $\mathrm{Ni}$ and Fe clusters (white phase); (ii) $\mathrm{Mg}_{2} \mathrm{Ni}$-type phase (grey phase). 
ates indicates that the formation reaction of this phase has not proceeded to completion. In the case of $\mathrm{Mg}_{2} \mathrm{Ni}_{07} \mathrm{Fe}_{03}$, the analysis shows the presence of $\mathrm{Fe}$ agglomerates and a small amount of $\mathrm{Ni}$ clusters along with the $\mathrm{Mg}_{2} \mathrm{Ni}$-type phase. This is visualized in the backscattering microphotograph in Fig. 2. Comparing data on both samples with $\mathrm{Fe}$ substitution one can conclude that in $\mathrm{Mg}_{2} \mathrm{Ni}_{0} \mathrm{Fe}_{03}$ the formation of the $\mathrm{Mg}_{2} \mathrm{Ni}$ phase has proceeded more completely than in the case of $\mathrm{Mg}_{2} \mathrm{Ni}_{09} \mathrm{Fe}_{01}$.

The results of the first hydriding cycle of the composites with the nominal composition 85 wt.\% $\mathrm{Mg}-15$ wt.\% $\mathrm{Mg}_{2} \mathrm{Ni}_{1-x} \mathrm{Fe}_{x}$ are shown in Fig. 3. As it is evident from the figure, all the three composites reach a high absorption capacity without preliminary activation, which would have been necessary for magnesium, its alloys and the mechanically alloyed systems obtained on its basis.

Figs. 4-6 present the kinetic curves of hydriding at different temperatures and a pressure of $1 \mathrm{MPa}$. The relatively high hydrogen capacity reached at low hydriding temperatures (473 and $373 \mathrm{~K}$ ), which is not observed with other magnesium composites containing intermetallics should be noted in this case. Obviously, the rate of absorption for the composites $\mathrm{Mg}-\mathrm{Mg}_{2} \mathrm{Ni}_{1-x} \mathrm{Fe}_{x}$ is appreciable even in the case when the driving force $\left(P_{\text {applied }}{ }^{-}\right.$ $\left.P_{\text {eq }}\right)$ is reduced. This fact may be important from the point of view of future application.

The kinetic curves of hydriding at $573 \mathrm{~K}$ for the three composites (Fig. 7) show no substantial difference in the proceeding of hydrogen absorption. However, the difference is distinct when comparing the results for 623 and $573 \mathrm{~K}$ (Figs. 8-10). With the three composites, hydriding at $573 \mathrm{~K}$ occurs at a higher rate than it does at $623 \mathrm{~K}$. The

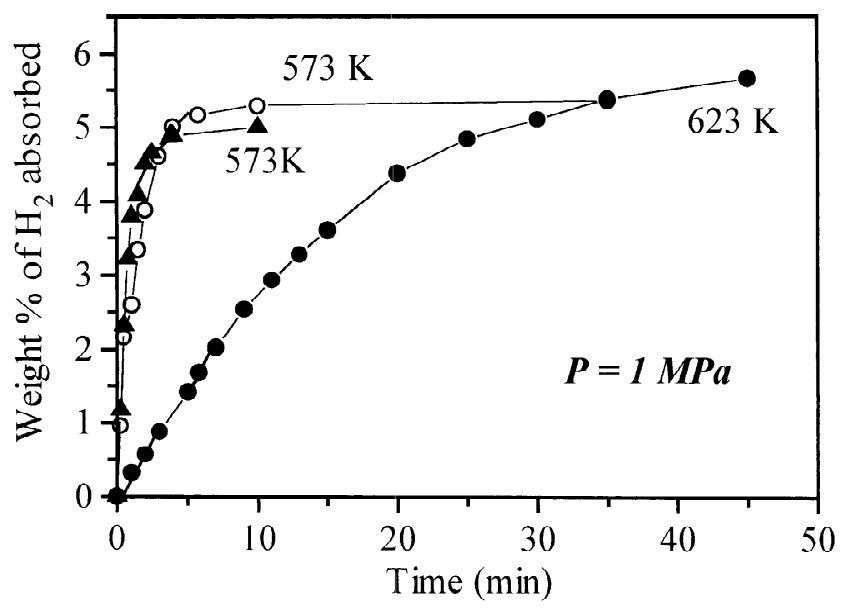

Fig. 3. Kinetic curves of hydriding during the first cycle of composites with nominal compositions: $(\bullet) 85$ wt. $\% \mathrm{Mg}-15$ wt. $\% \mathrm{Mg}_{2} \mathrm{Ni}$; (○) 85

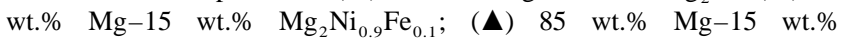
$\mathrm{Mg}_{2} \mathrm{Ni}_{0.7} \mathrm{Fe}_{0.3}$.

presence of $\mathrm{Fe}$ and the lower content of $\mathrm{Mg}_{2} \mathrm{Ni}$ retard the hydriding process. This effect can be ascribed to the fact that at $573 \mathrm{~K}$ hydriding is accompanied by simultaneous formation of two hydrides, $\mathrm{MgH}_{2}$ and $\mathrm{Mg}_{2} \mathrm{NiH}_{4}$, whereas at $623 \mathrm{~K}$ it is $\mathrm{MgH}_{2}$ only that appears. Taking into account that at $573 \mathrm{~K}$ the ternary hydride is formed more easily than the magnesium hydride, this means that the formation of the ternary hydride ends at the beginning of the process, and a large number of nuclei appear on the particle surfaces. This fact determines the higher rate of hydriding at the above temperature. At $623 \mathrm{~K}$ nuclei of magnesium hydride only are obtained, due to which the hydriding proceeds with a lower rate. The oxygen contamination could also play an important role.

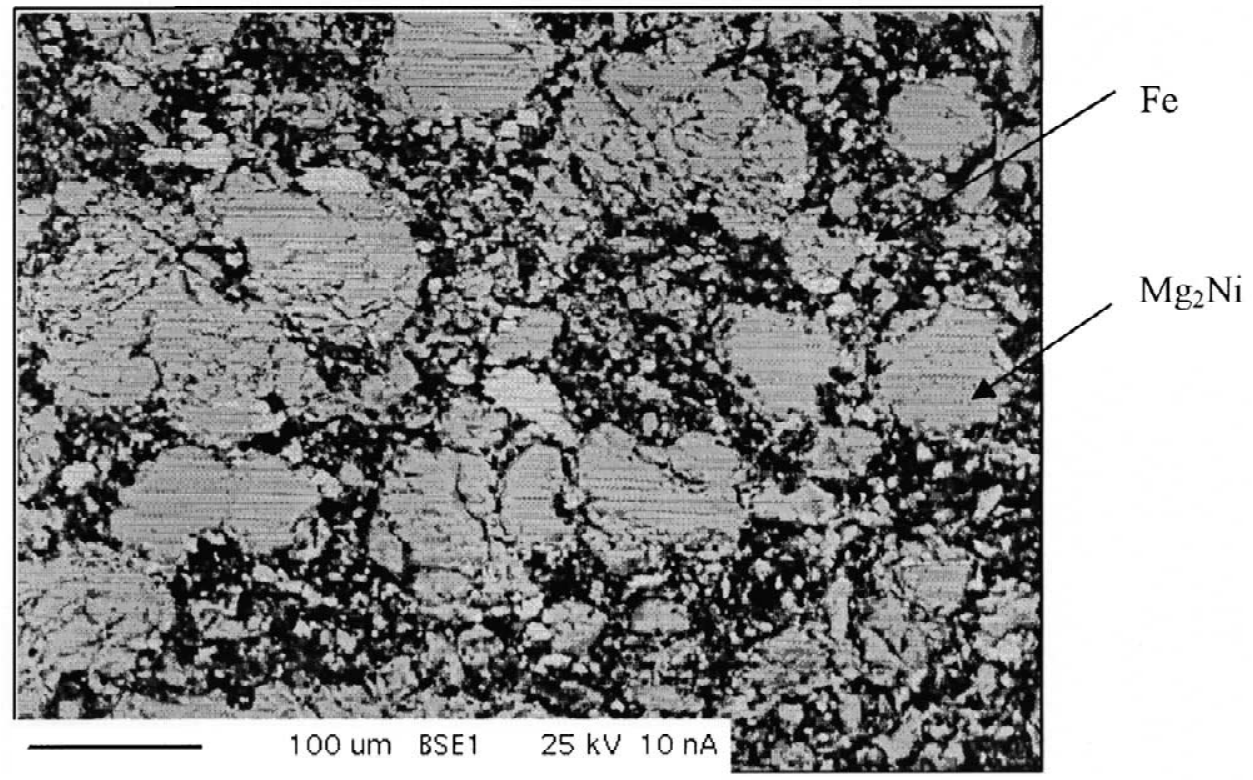

Fig. 2. Backscattering electron microphotograph of the $\mathrm{Mg}_{2} \mathrm{Ni}_{0.7} \mathrm{Fe}_{0.3}$ sample showing the presence of: (i) $\mathrm{Fe}$ (and some Ni) clusters (white phase); (ii) $\mathrm{Mg}_{2} \mathrm{Ni}$-type phase (grey phase). 


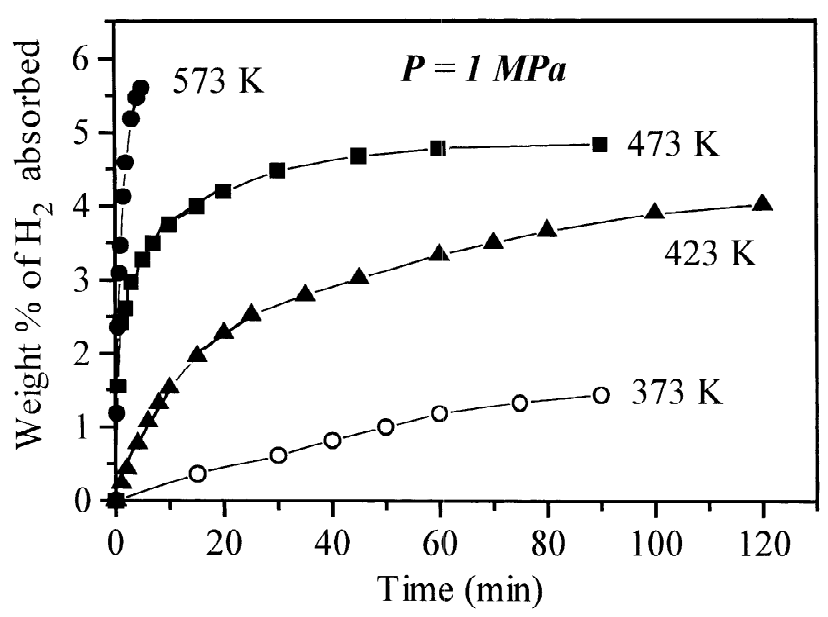

Fig. 4. Kinetic curves of hydriding of the composite 85 wt. $\% \mathrm{Mg}-15$ wt. $\% \mathrm{Mg}_{2} \mathrm{Ni}$ at different temperatures and $P=1 \mathrm{MPa}$.

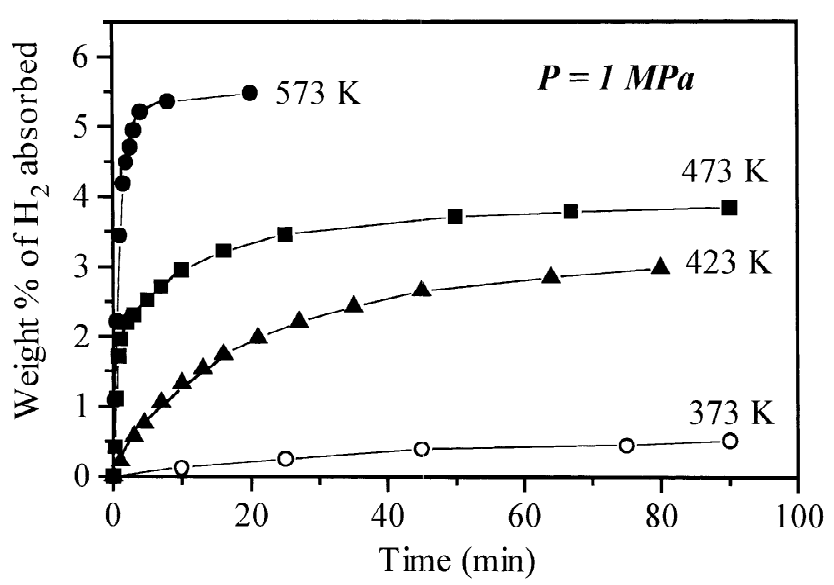

Fig. 5. Kinetic curves of hydriding of the composite 85 wt. $\% \mathrm{Mg}-15$ wt. $\% \mathrm{Mg}_{2} \mathrm{Ni}_{\mathrm{o}, 9} \mathrm{Fe}_{0,1}$ at different temperatures and $P=1 \mathrm{MPa}$.

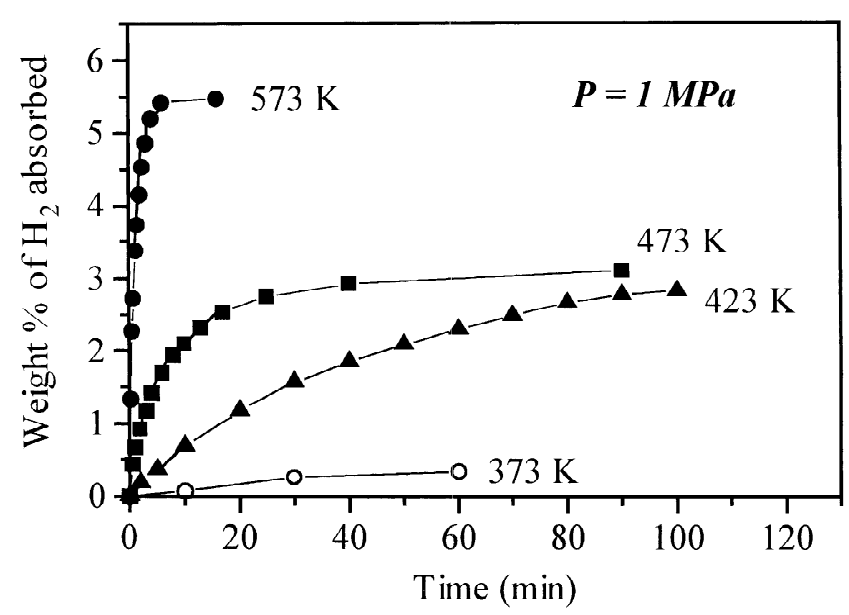

Fig. 6. Kinetic curves of hydriding of the composite 85 wt. $\% \mathrm{Mg}-15$ wt. $\% \mathrm{Mg}_{2} \mathrm{Ni}_{0,7} \mathrm{Fe}_{0,3}$ at different temperatures and $P=1 \mathrm{MPa}$.

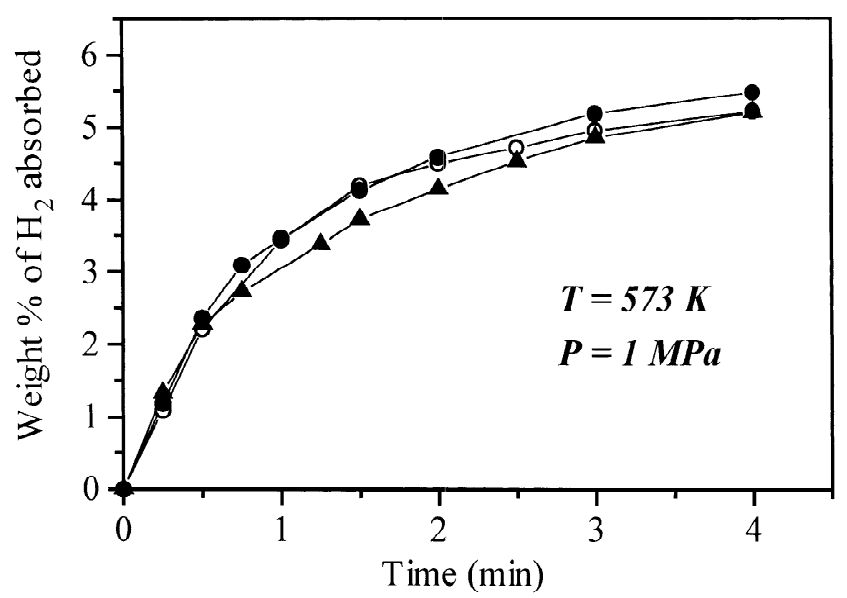

Fig. 7. Hydrogen absorption versus time behaviour during the beginning of the hydriding process of the composites $85 \mathrm{wt} . \% \mathrm{Mg}-15 \mathrm{wt} . \% \mathrm{Mg}_{2} \mathrm{Ni}$ (๑), 85 wt. $\% \mathrm{Mg}-15$ wt. $\%$. $\mathrm{Mg}_{2} \mathrm{Ni}_{0.9} \mathrm{Fe}_{0.1}(\bigcirc)$ and 85 wt.\% $\mathrm{Mg}-15$ wt. $\% \mathrm{Mg}_{2} \mathrm{Ni}_{0.7} \mathrm{Fe}_{0.3}(\boldsymbol{\Delta})$ at $T=573 \mathrm{~K}$ and $P=1 \mathrm{MPa}$.

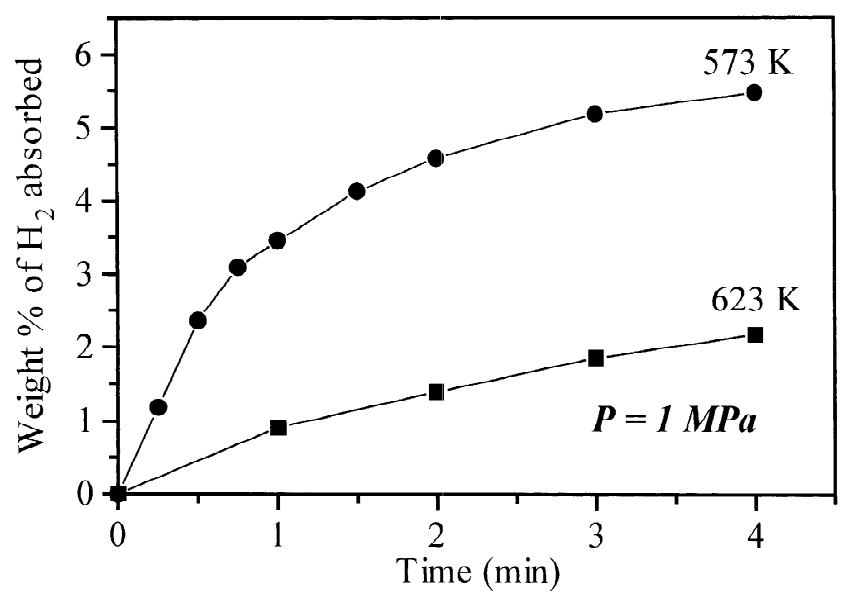

Fig. 8. Hydrogen absorption versus time behaviour during the beginning of the hydriding process of the composite $85 \mathrm{wt} . \% \mathrm{Mg}-15$ wt. $\% \mathrm{Mg}_{2} \mathrm{Ni}$ at temperatures of 573 and $623 \mathrm{~K}$ and a pressure of $1 \mathrm{MPa}$.

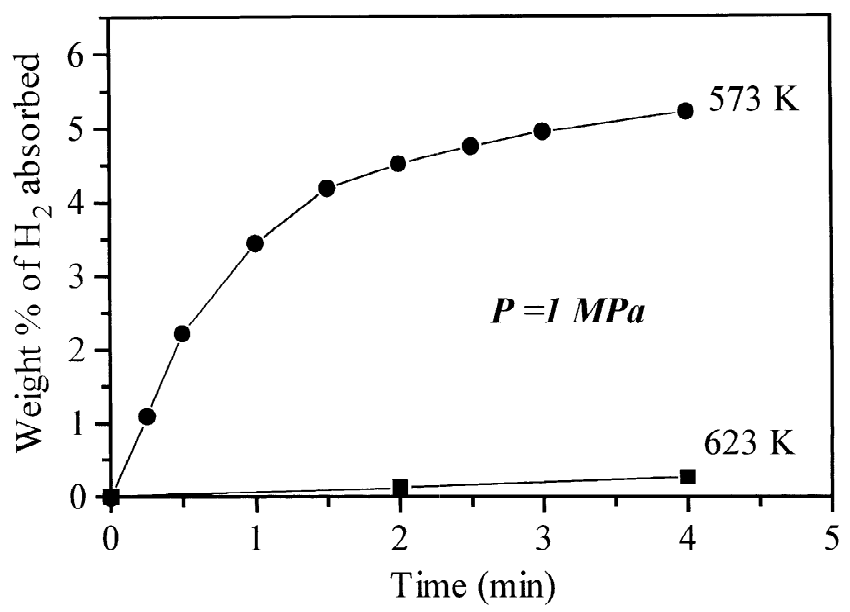

Fig. 9. Hydrogen absorption versus time behaviour during the beginning of the hydriding process of the composite 85 wt.\% $\mathrm{Mg}-15$ wt.\% $\mathrm{Mg}_{2} \mathrm{Ni}_{0.9} \mathrm{Fe}_{0.1}$ at temperatures of 573 and $623 \mathrm{~K}$ and a pressure of $1 \mathrm{MPa}$. 


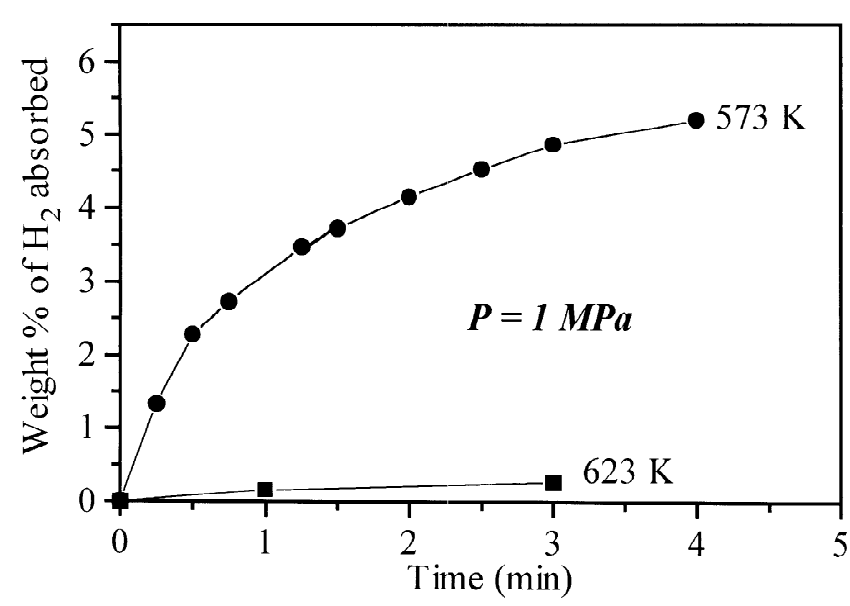

Fig. 10. Hydrogen absorption versus time behaviour during the beginning of the hydriding process of the composite 85 wt.\% $\mathrm{Mg}-15$ wt.\% $\mathrm{Mg}_{2} \mathrm{Ni}_{0.7} \mathrm{Fe}_{0.3}$ at temperatures of 573 and $623 \mathrm{~K}$ and a pressure of $1 \mathrm{MPa}$.

The high absorption capacity at lower hydriding temperatures and the improved hydriding kinetics at these temperatures are obviously a result of the catalytic action of $\mathrm{Mg}_{2} \mathrm{Ni}_{1-x} \mathrm{Fe}_{x}$ in the composites. The presence of the intermetallics, which is associated with the formation of the ternary $\mathrm{Mg}_{2} \mathrm{NiH}_{4}$ leads to a larger interface that facilitates the nucleation and growth of the hydride layer. On the other hand, when hydriding and desorption take place at $573 \mathrm{~K}$, superparamagnetic nickel and iron appear on the particle surfaces, which is evidenced by magnetic data. Segregated nickel on the $\mathrm{Mg}_{2} \mathrm{Ni}$ surface has also been found by Schlapbach et al. [27]. The hydriding kinetics is additionally improved by the process of mechanical alloying where the appearing defects and dislocations help the nucleation. The simultaneous presence of all these factors is the probable reason for both the proceeding

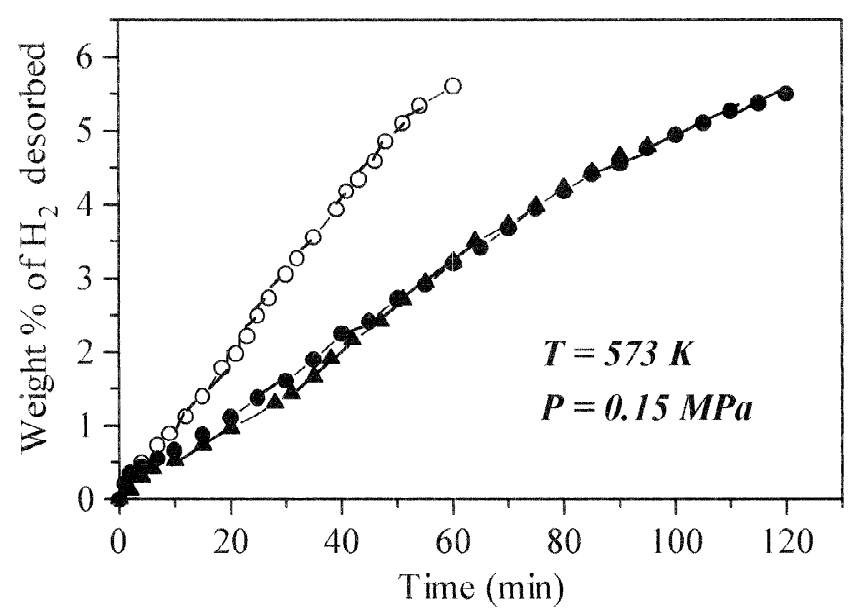

Fig. 11. Kinetic curves of dehydriding at $T=573 \mathrm{~K}$ and $P=0.15 \mathrm{MPa}$ of composites with nominal compositions: (O) 85 wt.\% $\mathrm{Mg}-15$ wt.\% $\mathrm{Mg}_{2} \mathrm{Ni}$; (○) 85 wt.\% $\mathrm{Mg}-15$ wt.\% $\mathrm{Mg}_{2} \mathrm{Ni}_{0.9} \mathrm{Fe}$; (ム) 85 wt.\% Mg-15 wt. $\% \mathrm{Mg}_{2} \mathrm{Ni}_{0.7} \mathrm{Fe}_{0.3}$. of the reaction at lower temperatures and the better kinetic behaviour of the composites during hydrogen absorption.

The catalytic effect of the $\mathrm{Mg}_{2} \mathrm{Ni}_{1-x} \mathrm{Fe}_{x}$ additive is more pronounced during hydriding of the composites than is the case of their dehydriding. This is illustrated by the kinetic curves of hydrogen desorption of the three composites at $573 \mathrm{~K}$ (Fig. 11). As it is evident from the figure, the presence of the catalytic additive is the reason for the higher rate of desorption which is usually relatively low for the magnesium systems at this temperature. The effect is most pronounced for the composite containing $\mathrm{Mg}_{2} \mathrm{Ni}_{09} \mathrm{Fe}_{01}$.

\section{Conclusion}

The investigation of the absorption-desorption characteristics of mechanically alloyed nanocomposites of magnesium and $\mathrm{Mg}_{2} \mathrm{Ni}_{1-x} \mathrm{Fe}_{x}$ intermetallics shows that the additives have a catalytic effect on the hydriding of magnesium which consists in:

(i) attaining a high absorption capacity without preliminary activation;

(ii) improving the hydriding kinetics at a temperature which is relatively low for magnesium-based systems;

(iii) a sufficiently high absorption capacity at low hydriding temperatures;

(iv) a reduced temperature of hydrogen desorption from the hydrided samples.

The catalytic effect observed is due to an increase in the $\mathrm{Mg} /$ hydride interface as a result of the formation of a second hydride $\left(\mathrm{Mg}_{2} \mathrm{NiH}_{4}\right)$ in the system, to the mechanical alloying and the presence of $\mathrm{Ni}$ and Fe clusters on the surface of nanocomposite particles.

\section{References}

[1] L. Zaluski, A. Zaluska, J.O. Ström-Olsen, J. Alloys Comp. 217 (1995) 245.

[2] H. Aoyagi, K. Aoki, T. Masumoto, J. Alloys Comp. 231 (1995) 804.

[3] S. Orimo, K. Ikeda, H. Fujii, Y. Fujikawa, Y. Kitano, K. Yamamoto, Acta Mater. 45 (1997) 2271.

[4] L. Zaluski, A. Zaluska, P. Tessier, J.O. Ström-Olsen, R. Schulz, J. Alloys Comp. 217 (1995) 295.

[5] K.J. Gross, P. Spatz, A. Züttel, L. Schlapbach, J. Alloys Comp. 261 (1997) 276.

[6] E.Yu. Ivanov, I.G. Konstanchuk, A.A. Stepanov, V.V. Boldyrev, Dokl. Akad. Nauk SSSR 286 (1986) 385.

[7] I.G. Konstanchuk, E.Yu. Ivanov, M. Pezat, B. Darriet, V.V. Boldyrev, P. Hagenmuller, J. Less-Common Met. 131 (1987) 181.

[8] J.-L. Bobet, E. Akiba, B. Darriet, Int. J. Hydrogen Energy 26 (2001) 493.

[9] A. Zaluska, L. Zaluski, J.O. Ström-Olsen, Appl. Phys. A, Mater. Sci. Proc. 72 (2001) 157.

[10] L.E.A. Berlouis, E. Cabrera, E. Hall-Barientos, P.J. Hall, S.B. Dodd, S. Morris, M.A. Imam, J. Mater. Res. 16 (2001) 45. 
[11] M. Terzieva, M. Khrussanova, P. Peshev, J. Alloys Comp. 267 (1998) 235.

[12] G. Liang, S. Boily, J. Huot, A. Van Neste, R. Schulz, J. Alloys Comp. 267 (1998) 302.

[13] G. Liang, S. Boily, J. Huot, A. Van Neste, R. Schulz, J. Alloys Comp. 268 (1998) 302.

[14] G. Liang, J. Huot, S. Boily, A. Van Neste, R. Schulz, J. Alloys Comp. 297 (2000) 261.

[15] M. Terzieva, M. Khrussanova, P. Peshev, D. Radev, Int. J. Hydrogen Energy 20 (1995) 53.

[16] S.S. Sai Raman, D.J. Davidson, O.N. Srivastava, J. Alloys Comp. 292 (1999) 202.

[17] M. Zhu, Y. Gao, X.Z. Che, Y.Q. Yang, C.Y. Chung, J. Alloys Comp. 330-332 (2002) 708.

[18] M. Khrussanova, J.-L. Bobet, M. Terzieva, B. Chevalier, D. Radev, P. Peshev, B. Darriet, J. Alloys Comp. 307 (2000) 283.
[19] L. Guoxian, W. Erde, F. Shoushi, J. Alloys Comp. 223 (1995) 111. [20] J. Yang, M. Cuireanu, R. Roberge, Mater. Lett. 43 (2000) 234.

[21] P. Wang, A. Wang, H. Zhang, B. Ding, Z. Hu, J. Alloys Comp. 297 (2000) 240.

[22] P. Wang, H.F. Zhang, B.Z. Ding, Z.Q. Hu, Acta Mater. 49 (2001) 921.

[23] S. Orimo, H. Fujii, Appl. Phys. A, Mater. Sci. Proc. 72 (2001) 167.

[24] M. Khrussanova, E. Grigorova, I. Mitov, D. Radev, P. Peshev, J. Alloys Comp. 327 (2001) 230.

[25] B. Tanguy, J.L. Soubeyroux, M. Pezat, J. Portier, P. Hagenmuller, Mater. Res. Bull. 11 (1976) 1441.

[26] J.P. Darnaudery, B. Darriet, M. Pezat, Int. J. Hydrogen Energy 8 (1983) 705.

[27] L. Schlapbach, D. Shaltiel, P. Oelhafen, Mater. Res. Bull. 14 (1979) 1235. 